\title{
Fish communities of the Wilderness Lakes System in the southern Cape, South Africa
}

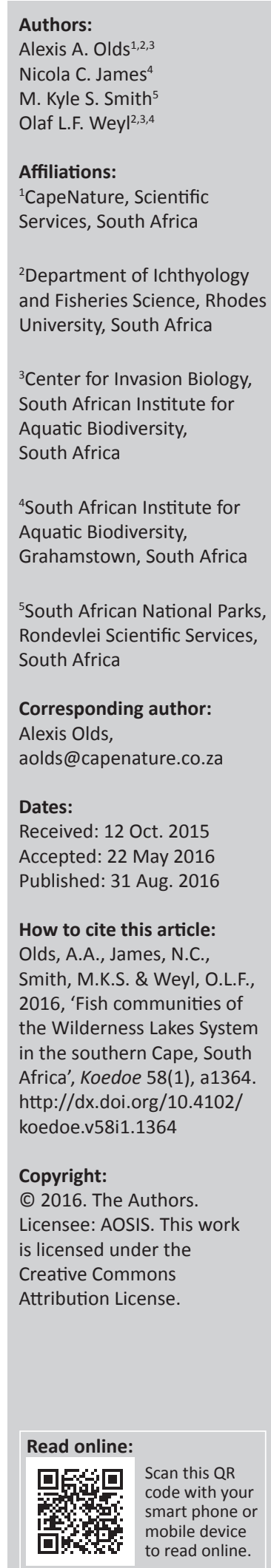

The Wilderness Lakes System, a temporarily open and closed estuary with three associated lakes situated in the southern Cape region of South Africa, was sampled using a range of sampling gears to assess the fish community. A total of 25 species were sampled throughout the system, with the highest diversity in the Touw Estuary (23 species) and the lowest in Langvlei (11 species). Estuary-associated marine species (13 species) dominated species richness with smaller proportions of estuarine resident (7 species), freshwater (3 species) and catadromous species ( 2 species). Estuarine resident species dominated the catch numerically. The size-class distribution of euryhaline marine species indicated that upon entering the Touw Estuary as juveniles, the fish move up the system towards Rondevlei where they appear to remain. Three freshwater species were recorded in the system, all of which are alien to the Wilderness Lakes System. Decreasing salinity in the upper lakes appears to be a driving factor in the distribution and increasing abundance of the freshwater fishes. Sampling followed a drought, with the system experiencing substantially increased levels of mouth closure compared to a similar study conducted in the 1980s. The timing of mouth opening and the degree of connectivity between the lakes influence the nursery function of the system as a whole. Management actions need to focus on improving ecological functioning of this system, in particular how mouth opening is managed, to facilitate nursery function and limit the establishment of invasive species.

Conservation implications: Key management actions are required to improve fish recruitment potential into and within the system. These include maintenance of adequate marine inflow through adherence to artificial mouth breaching protocols and improving connectivity between the lakes through sediment removal from localised deposition points within the connecting channels.

\section{Introduction}

The Wilderness Lakes System (Figure 1) comprise a series of three coastal lakes and a temporarily open and closed estuary connected by shallow channels. It is located on the warm-temperate south coast of South Africa between the towns of George $(16 \mathrm{~km})$ and Knysna $(40 \mathrm{~km})$. The national conservation importance of the Wilderness Lakes System (hereafter referred to as Wilderness Lakes) has been assessed in several studies (Maree, Whitfield \& Quinn 2003; Turpie et al. 2002). The Wilderness Lakes is an important component of the Garden Route National Park vision, namely 'An integrated protected area that effectively conserves a functionally linked mosaic of diverse terrestrial, freshwater, estuarine and marine ecosystems, landscapes, and cultural heritage, representative of the Garden Route, that contributes to the well-being of present and future generations' (SANParks 2012:28).

Major threats to the system include alien invasive species, development pressure, water resource management and climate change (SANParks 2012). To be effective, management interventions will need to be guided by a sound understanding of the physical, biological and social components of the system. Estuaries constitute important nursery areas for a number of estuary-associated fish species (Potter \& Hyndes 1999; Whitfield 1994), and as such fish assemblages have been used as indicators of estuary ecosystem health (e.g. Harrison \& Whitfield 2004; Whitfield \& Elliott 2002). An understanding of the relative abundances and species composition of fish communities in estuaries is therefore important for guiding management actions as they reflect the state of the estuary.

Although fish communities in the Wilderness Lakes have been previously studied (Hall 1985; Hall, Whitfield \& Allanson 1987; Olds et al. 2011; Russell 1996, 1999), the last assessment of the fish community throughout the system using multiple gear types was undertaken in the 1980s by Hall (1985) and Hall et al. (1987). As a result, an assessment of the present state of the fish community allows for spatial comparisons across estuaries and temporal assessments of change within an 


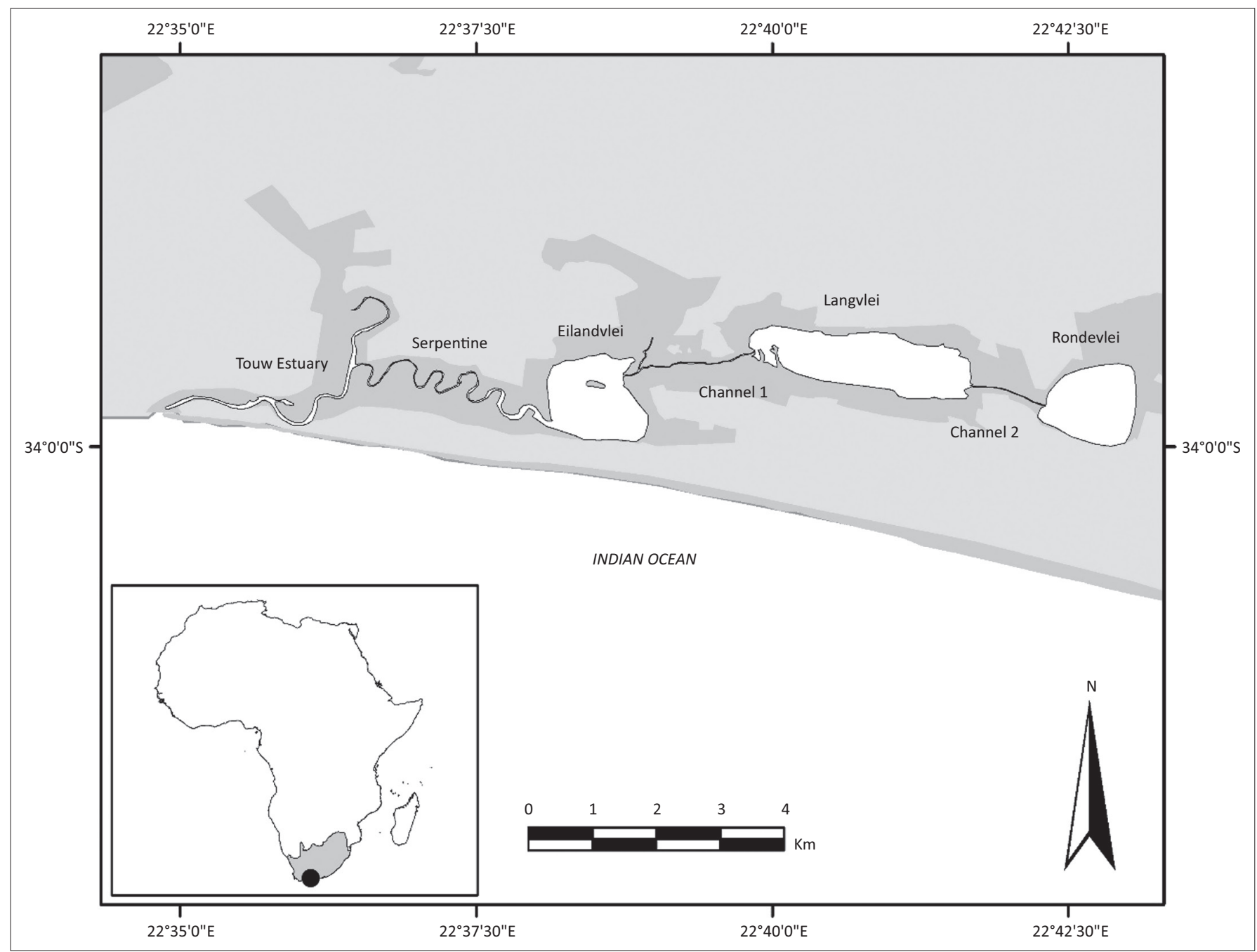

FIGURE 1: Map of the Wilderness Lakes System.

estuary. This paper describes a basic assessment of the abundance and distribution of fish species throughout the Wilderness Lakes in 2010-2011 and uses the relative abundance and species composition data to highlight management needs for this important estuarine lakes system.

\section{Study area}

The Wilderness Lakes is comprised of three coastal lakes: the first two, Eilandvlei and Langvlei, are barrier lagoons and the third, Rondevlei, is a deflation basin that has been artificially connected by a channel to Langvlei (Hall et al. 1987). The lakes provide a flood plain for the Touw River and Estuary (Figure 1). The depth of the Touw Estuary varies from $1.5 \mathrm{~m}$ to $3 \mathrm{~m}$ (Hall et al. 1987; Russell 2003). Rondevlei is the smallest lake with a surface area of $1.43 \mathrm{~km}^{2}$ and a maximum depth of $6 \mathrm{~m}$. Langvlei is the shallowest lake with a maximum depth of $4 \mathrm{~m}$, but has the largest surface area of $2.16 \mathrm{~km}^{2}$. Eilandvlei has a maximum depth of $6.5 \mathrm{~m}$ and is the deepest in the system, with a surface area of $1.5 \mathrm{~km}^{2}$ (Hall et al. 1987). Under drought conditions, the water levels in the system drop significantly, resulting in the separation of Rondevlei, Langvlei and the connecting channel. This scenario was observed between March and May 2010 during the study period.
The Touw Estuary is a temporarily open and closed estuary that is closed off from the sea for varying periods by a sandbar at the mouth. Under pristine conditions, the estuary opened approximately $40 \%$ of the time. Opening of the estuary mouth has been managed by SANParks since the 1970s to prevent flooding of private property adjacent to the estuary (Russell 2013). When water levels in the estuary reach between $2.1 \mathrm{~m}$ and $2.4 \mathrm{~m}$ above mean sea level, the mouth is opened manually by SANParks. Declining freshwater inputs and artificial breaching have resulted in reduced opening of the estuary, with the estuary now only open approximately $28 \%$ of the time (Russell 2013). During this study, the estuary mouth was only open in July 2010 (4 days) and between December 2010 and January 2011 (28 days) (Figure 2b).

The Wilderness Lakes often exhibits a reverse salinity gradient, with the salinity increasing higher up the system towards Rondevlei (Allanson \& Whitfield 1983). Tidal penetration into the lakes is minor during open phases, with higher salinities in Rondevlei and Langvlei caused by low or no freshwater input into these lakes (Russell 2013). A reverse salinity gradient was present throughout the study period, with the highest salinities (mean \pm s.d.: 10.1 ppt $\pm 0.2 \mathrm{ppt}$ ) 

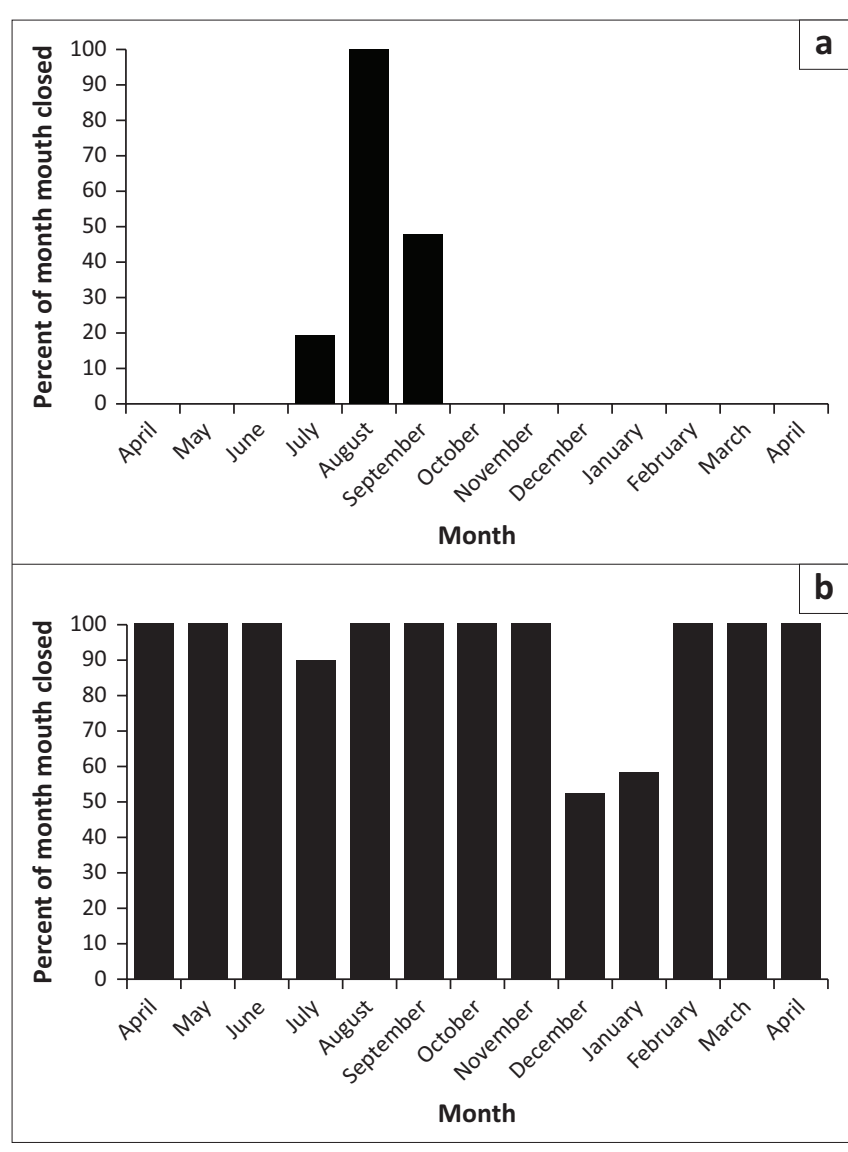

FIGURE 2: Mouth state of the Touw Estuary between (a) April 1982 and April 1983 (Hall 1985) and (b) between April 2010 and April 2011.

recorded in Langvlei and the lowest in the Touw Estuary (mean \pm s.d.: 4 ppt $\pm 2.3 \mathrm{ppt}$ ). Surface water temperature varied little across the system, but varied seasonally with relatively warm summer (mean \pm s.d.: $26.0^{\circ} \mathrm{C} \pm 0.9^{\circ} \mathrm{C}$ ) and mild winter (mean \pm s.d.: $13.6^{\circ} \mathrm{C} \pm 0.6^{\circ} \mathrm{C}$ ) temperatures.

The Wilderness Lakes are bordered by a margin of emergent aquatic plants predominantly made up of Phragmites australis (common reed) and, to a lesser extent, Juncus kraussii (dune slack rush), Schoenoplectus scirpoides (Biesiegoed) and Typha capensis (bulrush) (Russell 2003). Submerged aquatic macrophytes occur in each of the lakes and are mostly made up of stands of Potamogeton pectinatus (fennel pondweed), Charophyta and filamentous algae (Cladophora spp.). Zostera capensis (eelgrass) occurs sporadically in the Touw Estuary (Allanson \& Whitfield 1983; Howard-Williams \& Liptrot 1980; Weisser \& Howard-Williams 1982). During drought conditions, the density of aquatic vegetation decreases, which is assumed to be the result of increased salinity levels.

\section{Research method and design}

The system was sampled using a seasonally and geographically stratified sampling design between April 2010 and January 2011. The year was divided into four seasonal sampling periods, namely, autumn (April 2010), winter (July 2010), spring (October 2010) and summer (January 2011). Three different net types were used to sample as wide of a range of habitats, species and size classes as possible.
Each season, 12 double-ended fyke nets $(8 \mathrm{~m}$ guiding net, first-ring diameter of $55 \mathrm{~cm}$ and $10 \mathrm{~mm}$ mesh size at the cod end) were set randomly in each of the lakes (a total of 48 fyke nets per lake) whilst six fyke nets were randomly set within the middle and upper reaches of the Touw Estuary (a total of 24 fyke nets). Fyke nets are a passive gear type and were set in water at a depth of approximately $1 \mathrm{~m}-1.5 \mathrm{~m}$. Many of these areas were on the verge between sandy substrates and beds of P. pectinatus. All fyke nets were fitted with an 'otter guard' comprising plastic mesh with openings no larger than $10 \mathrm{~cm} \times 10 \mathrm{~cm}$ to prevent Cape clawless otters, Aonyx capensis, from entering. Although the use of otter guards influenced the maximum size of fish that could be sampled, their use was considered critical to avoid bycatch. Fyke nets were set between 16:00 and 18:00 and lifted the next morning in sequence between 06:00 and 08:00 with an average soak time of $16 \mathrm{~h}$.

A set of three multi-meshed gill nets each measuring $35 \mathrm{~m} \times 2.75 \mathrm{~m}$ with stretch meshes of $35 \mathrm{~mm}, 45 \mathrm{~mm}, 57 \mathrm{~mm}$, $73 \mathrm{~mm}, 93 \mathrm{~mm}, 118 \mathrm{~mm}$ and $150 \mathrm{~mm}$ ( $5 \mathrm{~m}$ per mesh size) were set for two consecutive nights per season in different positions in each of the lakes. Two nets were set once per season in the upper and lower reaches of the Touw Estuary. Gill nets were deployed at sunset and had an average soak time of $2 \mathrm{~h}$. Several mesh sizes were used to eliminate the size and species selectivity, which could have caused potential problems when investigating population and size frequency analyses (Prchalová et al. 2009).

A large seine net $(30 \mathrm{~m}$ long $\times 2 \mathrm{~m}$ deep with a bag, $12 \mathrm{~mm}$ stretched mesh), laid from a boat approximately $30 \mathrm{~m}$ offshore, was used to target fish from the littoral and pelagic zones. Initially, three pulls at three sites were completed in each of the lakes and the Touw Estuary per season. Because of progressively increasing water levels and filamentous epiphytic algae (Enteromorpha spp.) growth, the number of pulls had to be reduced.

Fish caught were identified to species level, counted and measured to the nearest millimetre fork length (FL) or total length (TL) depending on species, and released alive where possible. Sub-sampling was used in cases where the catch comprised large numbers of small fish, from which total abundances were estimated. Where appropriate, the length frequency distribution (in $10 \mathrm{~mm}$ size classes) was calculated for the most abundant species within the system.

\section{Results and discussion Species composition}

During this study, a total of 25 species were caught (Tables 1 , 2 and 3). A total of 23 species were recorded in the Touw Estuary and Eilandvlei, 11 in Langvlei and 15 in Rondevlei. Of the species caught, euryhaline marine species were dominant (15 species), followed by estuarine resident species ( 7 species) and freshwater species (3 species). Estuarine resident species, particularly estuarine roundherring (Gilchristella aestuaria) and Cape silverside (Atherina breviceps), were the most 
TABLE 1: Relative abundance (\% abundance) of fish species caught in seine nets in the Wilderness Lakes System between April 2010 and January 2011.

\begin{tabular}{|c|c|c|c|c|c|}
\hline Scientific name & Common name & $\begin{array}{c}\text { Touw estuary } \\
(n=20535 \text { fish, } \mathbf{3 6} \text { nets) }\end{array}$ & $\begin{array}{l}\text { Eilandvlei ( } n=26764 \\
\text { fish, } 24 \text { nets) }\end{array}$ & $\begin{array}{c}\text { Langvlei ( } n=15878 \text { fish, } \\
15 \text { nets) }\end{array}$ & $\begin{array}{l}\text { Rondevlei ( } n=21681 \\
\text { fish, } 13 \text { nets) }\end{array}$ \\
\hline \multicolumn{6}{|l|}{ Euryhaline marine species } \\
\hline Lichia amia & Leervis & 0.01 & 0.01 & 0.00 & 0.00 \\
\hline Lithognathus lithognathus & White steenbras & 0.10 & 0.10 & 0.00 & 0.00 \\
\hline Liza richardsonnii & Southern mullet & 0.04 & 0.03 & 0.10 & 0.10 \\
\hline Monodactylus falciformis & Oval moony & 0.03 & 0.00 & 0.00 & 0.00 \\
\hline Mugil cephalus & Flathead mullet & 0.00 & $<0.01$ & 0.00 & 0.00 \\
\hline Mugilidae & Unidentified mullet & 0.20 & 0.00 & 0.00 & 0.00 \\
\hline Myxus capensis & Freshwater mullet & $<0.01$ & 0.00 & 0.02 & 0.00 \\
\hline Rhabdosargus holubi & Cape stumpnose & 0.20 & 0.10 & 0.00 & 0.00 \\
\hline \multicolumn{6}{|l|}{ Estuarine resident species } \\
\hline Atherina breviceps & Cape silverside & 60.10 & 54.00 & 15.30 & 26.50 \\
\hline Caffrogobius gilchristi & Prison goby & $<0.01$ & 0.00 & 0.00 & 0.00 \\
\hline Gilchristella aestuaria & Estuarine roundherring & 38.60 & 41.50 & 73.20 & 39.30 \\
\hline Psammogobius knysnaensis & Speckled sandgoby & 0.40 & 0.20 & 0.01 & 0.03 \\
\hline Redigobius dewaali & Checked goby & 0.01 & $<0.01$ & 0.00 & 0.00 \\
\hline Syngnathus acus & Longsnout pipefish & 0.10 & 0.02 & 0.00 & 0.02 \\
\hline \multicolumn{6}{|l|}{ Freshwater species } \\
\hline Cyprinus carpio & Common carp & $<0.01$ & 0.01 & 0.03 & 0.00 \\
\hline Gambusia affinis & Western mosquitofish & 0.20 & 0.00 & 0.00 & 0.00 \\
\hline Oreochromis mossambicus & Mozambique tilapia & 0.20 & 3.40 & 0.10 & 0.10 \\
\hline
\end{tabular}

TABLE 2: Relative abundance (\% abundance) of fish species caught in fyke nets in the Wilderness Lakes System between April 2010 and January 2011.

\begin{tabular}{|c|c|c|c|c|c|}
\hline Scientific name & Common name & $\begin{array}{c}\text { Touw estuary ( } n=522 \\
\text { fish, } 24 \text { nets) }\end{array}$ & $\begin{array}{l}\text { Eilandvlei ( } n=971 \\
\text { fish, } 48 \text { nets) }\end{array}$ & $\begin{array}{l}\text { Langvlei ( } n=1917 \\
\text { fish, } 48 \text { nets) }\end{array}$ & $\begin{array}{c}\text { Rondevlei ( } n=538 \\
\text { fish, } 48 \text { nets) }\end{array}$ \\
\hline \multicolumn{6}{|l|}{ Euryhaline marine species } \\
\hline Monodactylus falciformis & Oval moony & 5.40 & 0.40 & 0.10 & 0.00 \\
\hline Rhabdosargus holubi & Cape stumpnose & 1.00 & 0.70 & 0.00 & 0.00 \\
\hline Solea bleekeri & Blackhand sole & 0.60 & 0.10 & 0.00 & 0.00 \\
\hline Galeichthys feliceps & White sea catfish & 0.60 & 0.00 & 0.00 & 0.00 \\
\hline Anguilla mossambica & Longfin eel & 0.20 & 0.10 & 0.00 & 0.00 \\
\hline \multicolumn{6}{|l|}{ Estuarine resident species } \\
\hline Caffrogobius gilchristi & Prison goby & 35.40 & 2.00 & 0.00 & 0.00 \\
\hline Psammogobius knysnaensis & Speckled sandgoby & 0.00 & 0.00 & 0.00 & 0.40 \\
\hline \multicolumn{6}{|l|}{ Freshwater species } \\
\hline Oreochromis mossambicus & Mozambique tilapia & 62.50 & 96.60 & 99.90 & 99.60 \\
\hline
\end{tabular}

abundant species recorded (with more than 10000 individuals caught). Seine net catches in all water bodies were dominated numerically by estuarine roundherring (G. aestuaria) and Cape silverside (A. breviceps), which together comprised between 66\% (Rondevlei) and 99\% (Touw Estuary) of the catch (Table 1). The freshwater species Mozambique tilapia (Oreochromis mossambicus) was also numerically abundant in the system, with more than 5000 individuals sampled. Mozambique tilapia comprised between $63 \%$ of the catch (Touw Estuary) and 99.9\% (Langvlei and Rondevlei) of the fyke net catch (Table 2). Gill nets, which sampled larger individuals of marine and freshwater species, were dominated numerically by euryhaline marine species, particularly southern mullet (Liza richardsonii), which comprised between $10 \%$ (Langvlei) and 40\% (Eilandvlei) of the catch, and oval moony (Monodactylus falciformis), which comprised between 3\% (Eilandvlei) and 48\% (Langvlei) of the catch.

\section{Euryhaline marine species}

Oval moony was present throughout the system and was common in Langvlei and Rondevlei, where it comprised, respectively, $48 \%$ and $27 \%$ of the gill net catch (Table 3 ). Although this species commonly uses the middle and upper reaches of estuaries as nursery areas, adults $(>120 \mathrm{~mm}$ standard length [SL]) are generally found in the near-shore marine environment (Whitfield 1998). Individuals captured during this survey ranged in size from $13 \mathrm{~mm}$ FL to $228 \mathrm{~mm}$ FL and showed a bimodal length frequency distribution. The majority of small individuals in the $90 \mathrm{~mm}$ FL - $100 \mathrm{~mm}$ FL size class were caught in the Touw Estuary. Larger specimens represented by the $190 \mathrm{~mm}$ FL - $200 \mathrm{~mm}$ FL size class were caught in Langvlei and Rondevlei (Figure 3). The presence of individuals $>120 \mathrm{~mm}$ FL in the upper lakes suggests that they were trapped in the system.

Southern mullet was present in all water bodies and common (comprised more than $20 \%$ of the catch) in gill net catches in Eilandvlei and Rondevlei (Table 3). Common as juveniles and adults in estuaries in the Eastern and Western Cape, southern mullet is normally more abundant in the adjacent near-shore marine environment (Bennett 1989). Individuals captured during this survey were all large, 
TABLE 3: Relative abundance (\% abundance) of fish species caught in gill nets in the Wilderness Lakes System between April 2010 and January 2011.

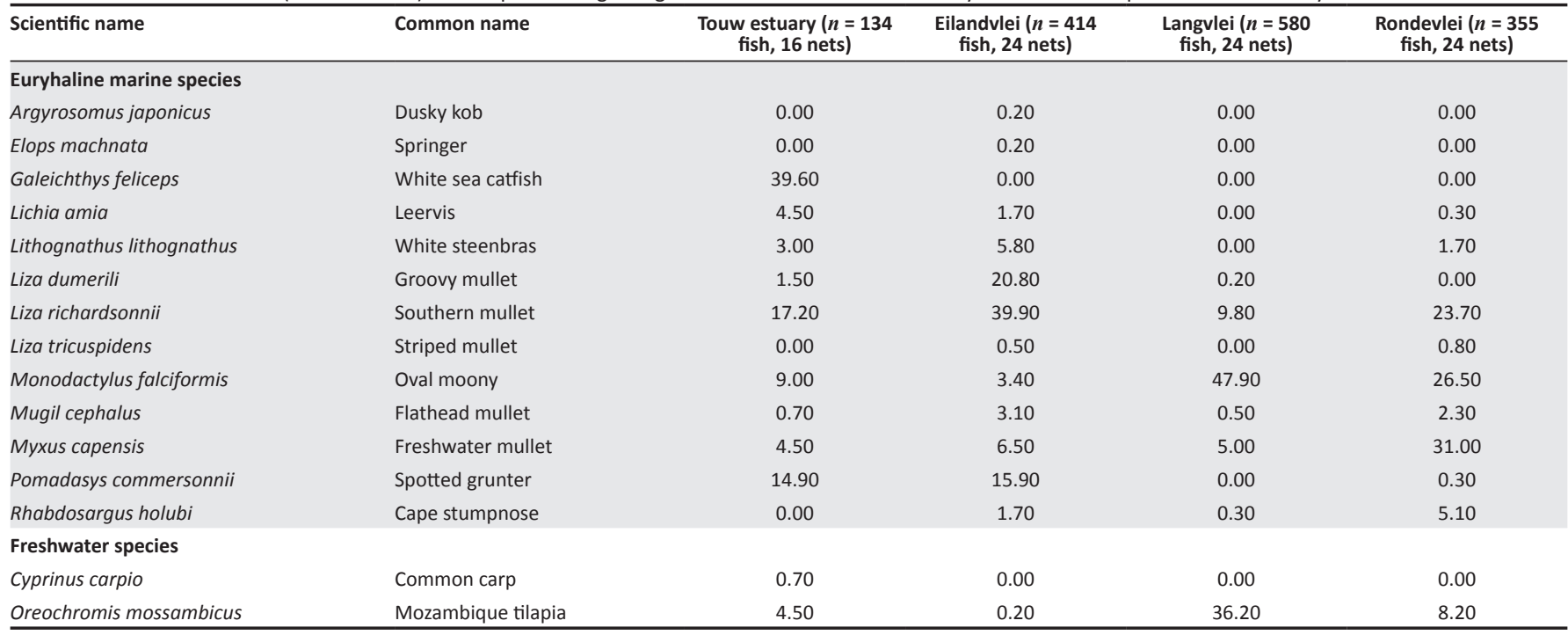

mature individuals ranging in size between $200 \mathrm{~mm}$ FL and $483 \mathrm{~mm}$ FL, with most individuals in the $340 \mathrm{~mm}$ FL $-350 \mathrm{~mm}$ FL size class (Figure 3). The smallest individuals were recorded in Eilandvlei. Maturing at $225 \mathrm{~mm} \mathrm{FL,} \mathrm{with}$ spawning taking place in the near-shore marine environment (De Villiers 1987; Van der Horst \& Erasmus 1981), they are usually more abundant in the lower and middle reaches of southern Cape estuaries (Whitfield \& Kok 1992). The abundance of adults, particularly in Langvlei and Rondevlei, during this study indicates possible entrapment in the upper lakes.

Although it is found as juveniles and adults in both estuaries and rivers, freshwater mullet (Myxus capensis) is often referred to as a catadromous species, with spawning occurring in the near-shore marine environment (Bok 1979). Freshwater mullet was present throughout the system, and increased in abundance in Rondevlei where it comprised $31 \%$ of the gill net catch (Table 3). Individuals showed a bimodal length frequency distribution; the first size class comprised individuals with a mode of $300 \mathrm{~mm}$ FL - $310 \mathrm{~mm}$ FL and the second size class comprised individuals with a mode of $380 \mathrm{~mm}$ FL - $390 \mathrm{~mm}$ FL. The larger individuals were found in Rondevlei (Figure 3).

Cape stumpnose (Rhabdosargus holubi), considered to be entirely dependent on estuarine habitats for the first year of life (Whitfield 1994), was present throughout the system and more common in Rondevlei where it comprised $5 \%$ of the gill net catch (Table 3). Cape stumpnose is often the most abundant marine species recorded in both temporarily open and closed and permanently open estuaries in the warmtemperate region of South Africa (Harrison 2005; Vorwerk et al. 2001). Individuals captured during this survey ranged in size from $120 \mathrm{~mm}$ FL to $420 \mathrm{~mm}$ FL with a polymodal length frequency distribution; the first size class comprised individuals with a mode of $140 \mathrm{~mm} \mathrm{FL} \mathrm{-} 160 \mathrm{~mm}$ FL, caught mainly in the Touw Estuary. The second size class comprised individuals with a mode of $230 \mathrm{~mm} \mathrm{FL} \mathrm{-} 240 \mathrm{~mm}$ FL, mainly from Eilandvlei, and the third size class comprised individuals with a mode of $340 \mathrm{~mm}$ FL - $350 \mathrm{~mm}$ FL from Rondevlei (Figure 3). Cape stumpnose normally migrate back to sea after reaching $120 \mathrm{~mm}$ SL. Some individuals, however, remain trapped in closed estuaries, where they reach sizes greater than $200 \mathrm{~mm}$ SL (James, Cowley \& Whitfield 2007a).

Large, predatory species such as leervis (Lichia amia) and springer (Elops machnata) were present in the estuary, Eilandvlei and Rondevlei, with one large leervis caught in Rondevlei (> 900 mm FL). Spotted grunter (Pomadasys commersonnii) and white steenbras (Lithognathus lithognathus), two important fishery species, showed a similar trend, with a greater proportion of smaller individuals sampled in the Touw Estuary and Eilandvlei and only a few very large individuals caught in Rondevlei (Table 3 and Figure 3). These species are all dependent on estuaries as nursery areas, but usually return to sea as sub-adults (Whitfield 1998).

\section{Estuarine resident species}

Seven estuarine resident species were caught, of which estuarine roundherring and Cape silverside were common or abundant in seine net catches in all water bodies. The other estuarine resident species, including prison goby (Caffrogobius gilchristi) (Touw Estuary and Eilandvlei) and speckled sandgoby (Psammogobius knysnaensis) (Touw Estuary, Eilandvlei and Rondevlei), were not caught in all water bodies. Cape silverside captured during this survey were between $16 \mathrm{~mm}$ FL and $100 \mathrm{~mm}$ FL. The majority (> 85\%) caught in Eilandvlei and Rondevlei were mature individuals ( $<40 \mathrm{~mm}$, Ratte 1989). In contrast, only 53\% of the individuals caught in the Touw Estuary and 59\% of the individuals caught in Langvlei were mature (Figure 4). Estuarine roundherring captured during this survey were between $20 \mathrm{~mm}$ FL and $89 \mathrm{~mm}$ FL, with the largest individuals caught in Rondevlei (Figure 4). Estuarine roundherring is estimated to mature at a size of $28 \mathrm{~mm}$ SL (Talbot 1982). 

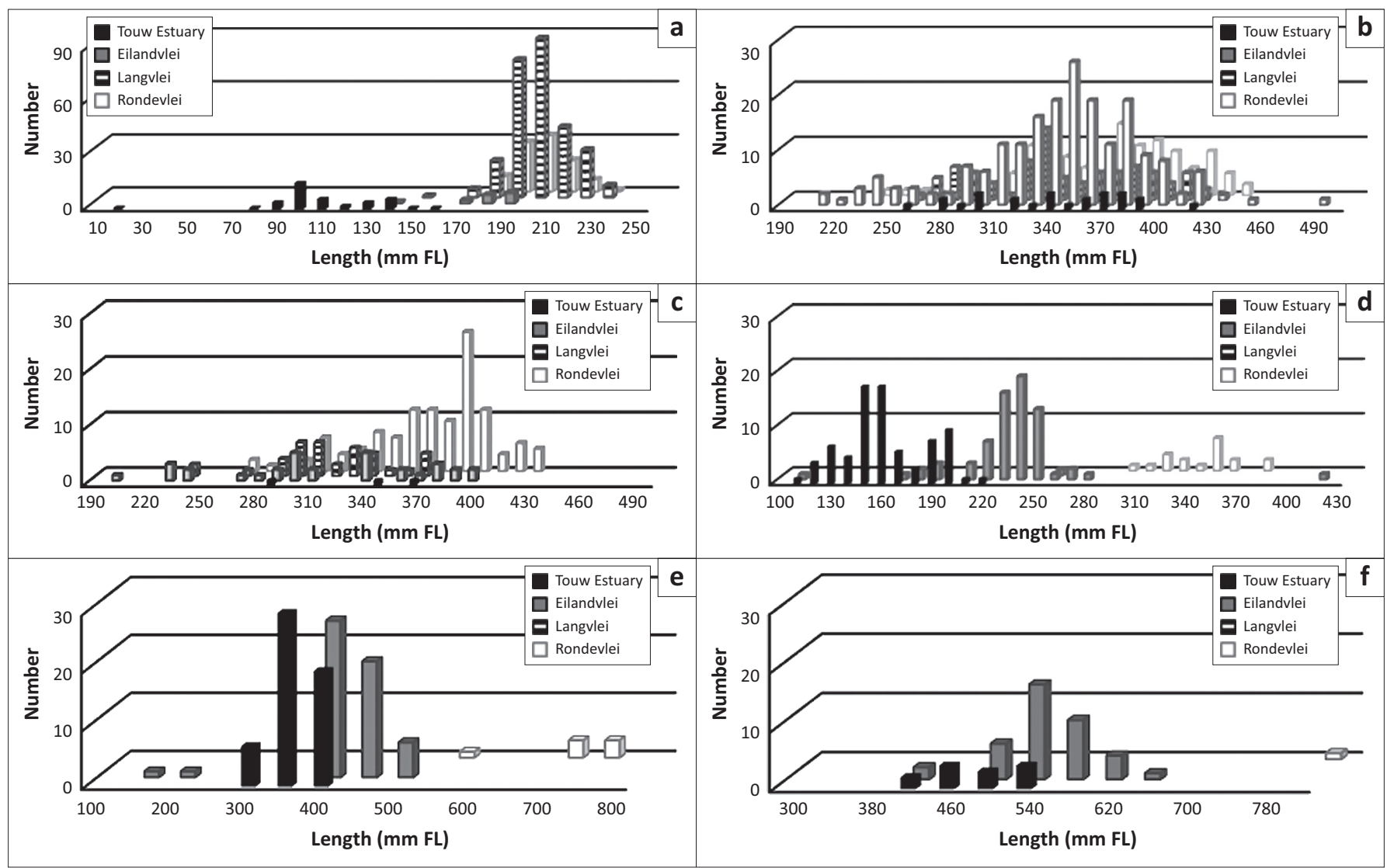

$n=$ (a) 449; (b) 413; (c) 189; (d) 180; (e) 116; (f) 78.

FIGURE 3: Length frequency of (a) Monodactylus falciformis, (b) Liza richardsonnii, (c) Myxus capensis, (d) Rhabdosargus holubi, (e) Lithognathus lithognathus and (f) Pomadasys commersonnii captured in the Wilderness Lakes System between April 2010 and May 2011.

\section{Freshwater species}

Three alien freshwater species, Mozambique tilapia, western mosquitofish (Gambusia affinis) and common carp (Cyprinus carpio), were sampled. Mozambique tilapia was abundant throughout the system (dominated fyke net catches in all sampling areas). Although endemic to southern Africa, Mozambique tilapia does not occur naturally south of the Bushmans Estuary in the Eastern Cape, but the species has been introduced extensively into farm dams as an angling fish in systems further south along the coastline, from which it has escaped. It is most abundant in temporarily open and closed estuaries during the closed phase (Whitfield \& Blaber 1979), possibly because of a combination of increased suitable nesting habitats during the closed phase and reduced recruitment success during open phases (Ellender et al. 2008). Although large individuals (> $200 \mathrm{~mm} \mathrm{FL}$ ) were caught throughout the system, the majority were small $(<180 \mathrm{~mm}$ FL) individuals (Figure 5).

The first formal record of the invasive common carp within the Wilderness Lakes was from Langvlei in 2009 (Olds et al. 2011), with fish measuring between $150 \mathrm{~mm}$ and $300 \mathrm{~mm}$. Larger specimens (500 mm FL - $800 \mathrm{~mm}$ FL) were sampled in 2010 in each of the lakes, whilst in 2011 three juveniles were sampled in the Touw Estuary (Figure 5). Together the data show a progression in size classes from 2009 to 2011 and confirms a successful spawning event having occurred in the Wilderness Lakes. Western mosquitofish were sampled in the $30 \mathrm{~m}$ seine net within the Touw Estuary during this study and previously in the Touw and Duiwe rivers by Russell (1999). This small species is most likely underrepresented in seine net samples because it is generally associated with marginal vegetation in the shallow littoral zone (Sloterdijk et al. 2015). Sloterdijk et al. (2015) sampled the Wilderness Lakes using scoup nets concurrently with this study and showed this species to be widespread and abundant throughout the system.

\section{General discussion}

The Wilderness Lakes is one of a few estuarine lakes systems in southern Africa, with only 3\% of southern African systems comprising estuarine lakes (Whitfield 1998). In common with other estuarine lakes in the warm-temperate region (such as Swartvlei, Bot and Klein), the fish fauna of the Wilderness Lakes is largely made up of euryhaline marine species, with smaller proportions of estuarine species and freshwater species (Bennett et al. 1985; Scott, Harrison \& Macnae 1952; Whitfield \& Kok 1992). Although the overall fish community is predominantly made up of marine species, estuarine resident fishes were numerically dominant in the seine nets, with estuarine roundherring and Cape silverside comprising the highest number of fish caught overall. The numerical dominance by Cape silverside and 

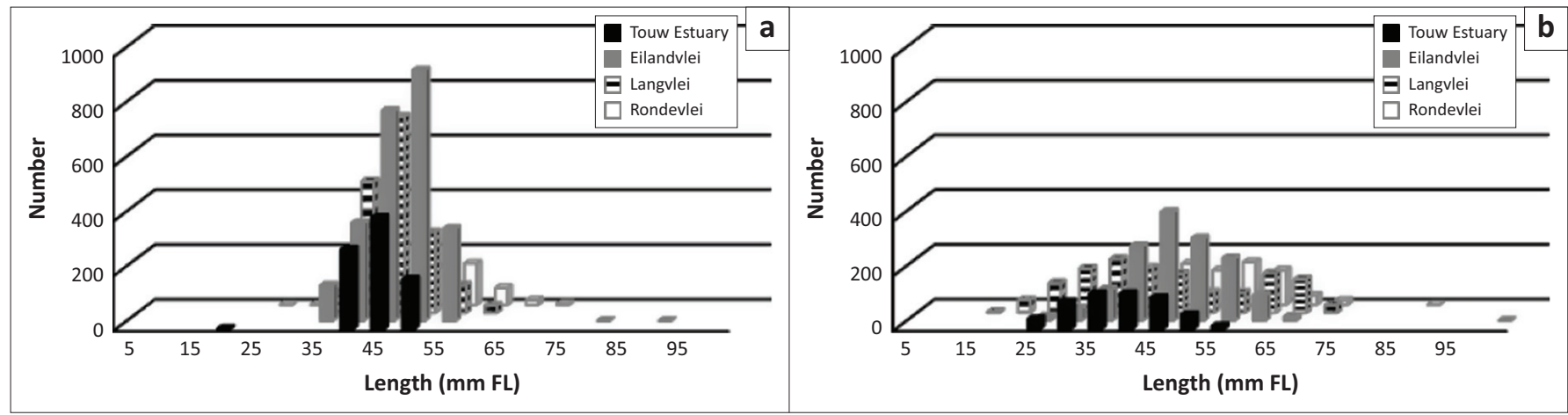

$n=($ a) $6081 ;$ (b) 4336

FIGURE 4: Length frequency of (a) Gilchristella aestuaria and (b) Atherina breviceps captured in the Wilderness Lakes System between April 2010 and May 2011.

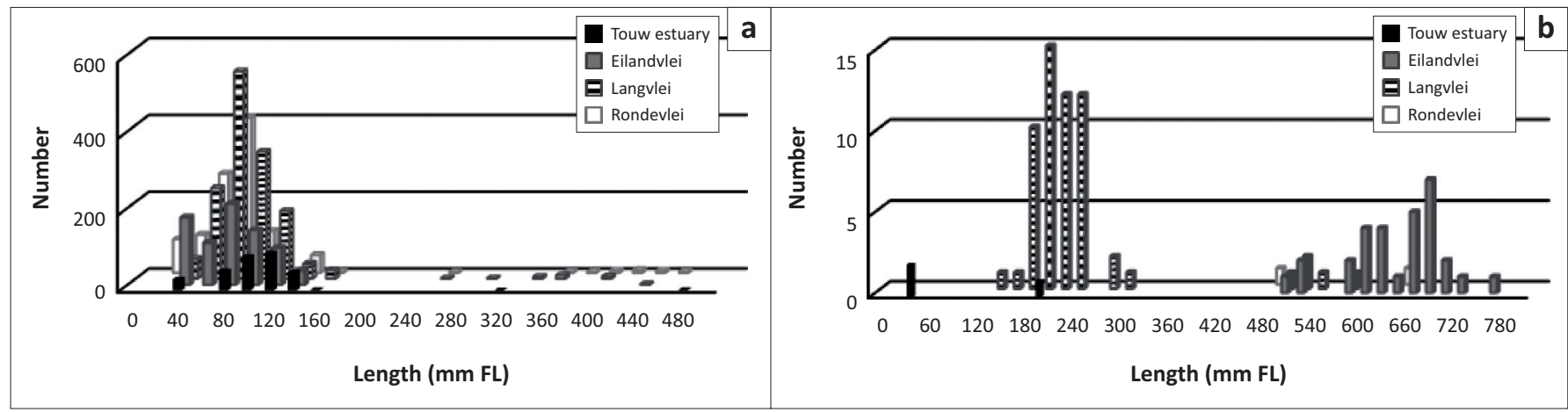

$n=$ (a) 5061; (b) 98 .

FIGURE 5: Length frequency of (a) Oreochromis mossambicus and (b) Cyprinus carpio captured in the Wilderness Lakes System between April 2010 and May 2011.

estuarine roundherring in the system was also noted by Hall (1985), James and Harrison (2008) and Olds et al. (2011). Within warm-temperate temporarily open and closed estuaries, estuarine resident species comprise well over $50 \%$ of the catch (by numbers) (James et al. 2007b). Although only a few species are able to complete their entire life cycle in estuaries (Day, Blaber \& Wallace 1981), short-lived estuarine resident species are well adapted to the estuarine environment and can dominate the fish communities of estuaries numerically (Potter et al. 1990). Cape silverside and estuarine roundherring comprised a larger percentage of the catch (by numbers) in temporarily open and closed estuaries on the southeast coast than in permanently open estuaries and also had a smaller mean size in temporarily open and closed estuaries than in permanently open estuaries (Vorwerk et al. 2001, 2003). This was attributed to a higher survival rate of smaller individuals in closed estuaries. The presence of a range of size classes of these species in the Wilderness Lakes may be attributed to the predominantly closed mouth and retention of size classes within the system.

The Touw Estuary and Eilandvlei had the highest species diversity (23 species), which was predominantly made up of euryhaline marine species, whilst Langvlei had the lowest species diversity (11 species). The low species diversity higher up the system was also noted by Hall (1985), with Langvlei and Rondevlei having low fish diversity. Hall (1985) sampled the estuary seasonally between April 1982 and April 1983 using similar gear. Hall (1985) and Hall et al. (1987) found that the depth of the interconnecting channels in Wilderness Lakes has a major influence on fish community structure in the lakes, with the marked decline in marine species richness between Eilandvlei and Langvlei attributed to the tenuous connection between these two lakes (Figure 6). In the first half of this study period, Langvlei and Rondevlei were also completely isolated from each other owing to a drought. In contrast, marine species dominate the lake compartments of the subtropical Kosi Bay system owing to a consistent connection between the lakes (Blaber 1978). Hall (1985) also recorded nine marine species in the estuary that were not found in the lake components of the system. These were mainly predatory species, such as dusky kob, leervis and white seacatfish (Galeichthys feliceps). Hall (1985) attributed this to the preference of these species for the deep, turbid waters of estuaries and their unwillingness to negotiate the shallow waters of the connecting Serpentine Channel. Interestingly, during this study, only one species, white seacatfish, was recorded in the Touw Estuary and not in the lakes.

White steenbras, leervis and spotted grunter were most abundant in Eilandvlei and in the Touw Estuary, with low numbers of very large fish sampled from Rondevlei. The decreasing abundance but increase in size of estuaryassociated marine species up the system was also reported by Hall (1985). The smaller fish found in Eilandvlei suggests that this lake serves as the system's initial nursery ground for the marine-spawned species (Hall 1985). Once these fish reach Rondevlei, it appears that they remain trapped there, which 


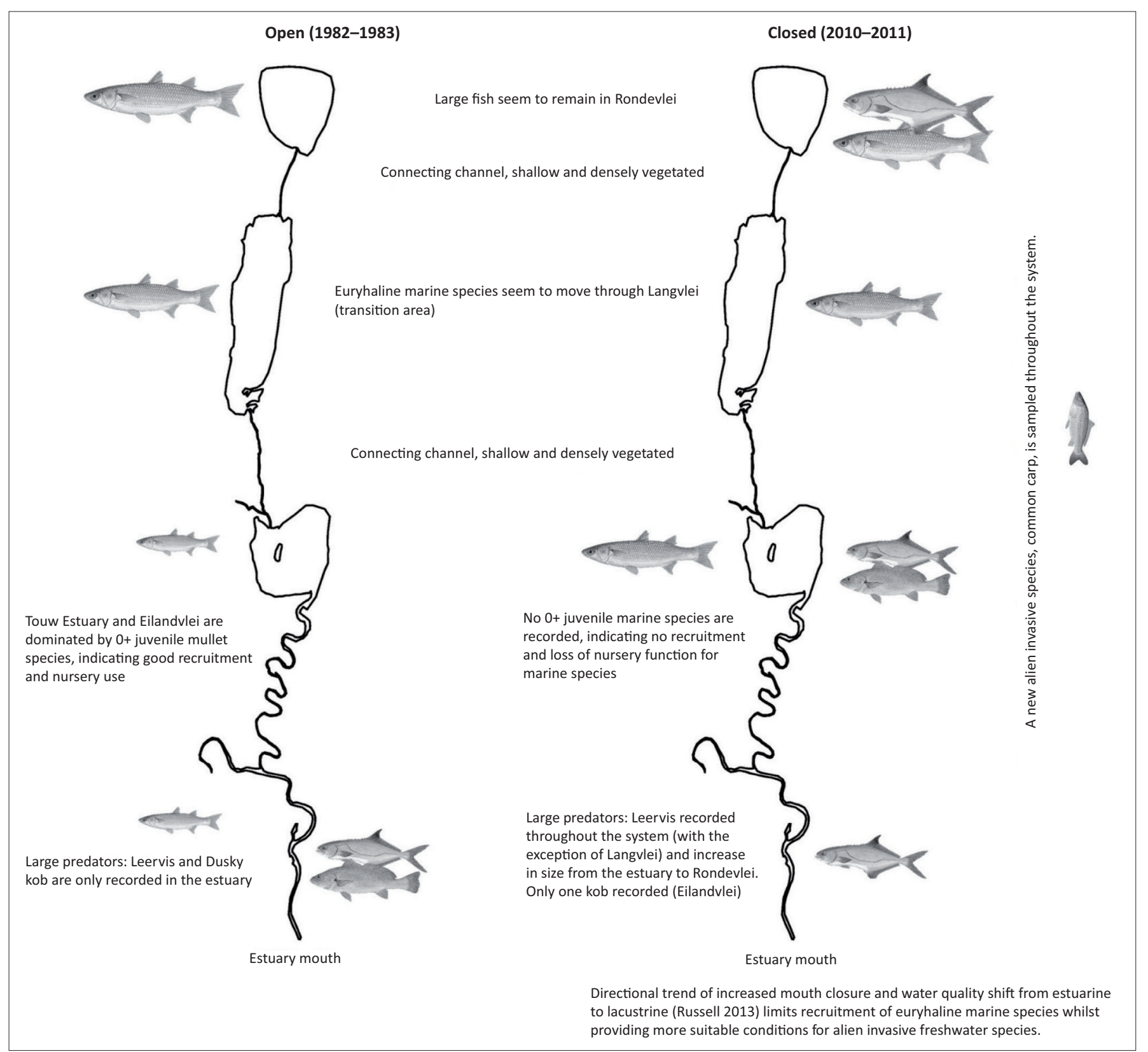

FIGURE 6: Comparison of the fish communities between a predominantly open phase (1982-1983) and a predominantly closed phase (2010-2011).

accounts for the presence of very large euryhaline marine fishes in Rondevlei. Langvlei had the lowest number of euryhaline marine species and it appears that these species either stay in Eilandvlei or move through to Rondevlei. With few euryhaline marine species being sampled by both Hall (1985) and us (in this study), it may be suggested that Langvlei acts as an intermediary or transition zone between the fresher Eilandvlei and more saline Rondevlei.

Numerous authors have suggested that the timing, frequency and duration of mouth opening events in temporarily open and closed estuaries affect species composition, particularly of marine species (Beckley 1984; Griffiths 1998; Kok \& Whitfield 1986; Wallace \& Van der Elst 1975; Young et al. 1997). In the warm-temperate East Kleinemonde Estuary, the timing of mouth opening had a significant effect on species composition (James, Whitfield \& Cowley 2008). Spring opening allowed for the regular recruitment of marine species into the estuary, many of which start entering Cape estuaries in late winter (August), with peak recruitment occurring during spring (September-November) (Whitfield 1998). The duration and frequency of mouth opening within a particular season appeared to have little impact on species composition in the East Kleinemonde Estuary (James et al. 2008).

During Hall's (1985) study, the estuary was open for $86 \%$ of the time, particularly during peak recruitment periods (late winter and spring) (Figure 2a), and mullet species in the Touw Estuary and Eilandvlei were dominated by $0+$ juveniles (> $50 \mathrm{~mm} \mathrm{SL}$ ), indicating good recruitment had occurred. In addition, Hall (1985) recorded 32 species from the system. Four of these species, blacktail (Diplodus sargus capensis), strepie (Sarpa salpa) (sampled in the Touw Estuary), Cape stumpnose (Eilandvlei) and super klipfish (Clinus superciliosus) 
(Rondevlei), were not sampled during this study. In contrast, the estuary only opened for 32 days ( $8 \%$ of the time) during this study between April 2010 and April 2011, and this was in summer and autumn (Figure 2b). Although the overall fish community composition was similar between the two periods, with catches dominated numerically by estuarine resident species, mullet and Mozambique tilapia, there were no 0+ juvenile southern mullet (< $180 \mathrm{~mm}$, De Villiers 1987), Cape stumpnose (<100 mm, Blaber 1974), freshwater mullet (< $100 \mathrm{~mm}$, Bok 1984), spotted grunter (< $150 \mathrm{~mm}$, Wallace 1975) or white steenbras (<120 mm, Bennett 1989) recorded. This indicates poor recruitment into the system during this period (Figure 6). Russell (1996) sampled the fish communities of both the Wilderness and Swartvlei lake systems and found that breaching of the estuaries during optimum fish recruitment periods resulted in an increase in the abundance of $0+$ juveniles in both systems. The duration of mouth opening had little impact on successful recruitment.

The widespread distribution and abundance of one extralimital and two alien invasive freshwater fishes is potentially concerning. Although Mozambique tilapia and western mosquitofish have been in the system for some time, the more recent introduction and spread of common carp in particular could have negative consequences. Because of its benthic foraging behaviour, the common carp resuspends particulate matter, which increases turbidity leading to decreased light penetration and submerged macrophyte abundance (Parkos, Santucci \& Wahl 2003). In addition, the foraging behaviour can increase the available nitrogen, ammonia and phosphorus available in the water column (Chumchal, Nowlin \& Drenner 2005), potentially promoting algal blooms and further environmental degradation (Khan, Wilson \& Khan 2003; Weber \& Brown 2009). A long-term water quality dataset for the Wilderness Lakes (Russell 2013) indicates a significant decrease in salinity in the upper lakes; if this continues it may improve conditions for these three species at the expense of endemic euryhaline marine and estuarine resident species. Future research work should shift towards understanding the ecological role and impacts of these species on the system.

\section{Conservation implications}

Improving or maintaining the ecological functioning of the Wilderness Lakes requires management actions to halt observed directional changes in water quality trends and improve connectivity between lakes. In particular, as in other systems, the structure of the marine fish community is determined by the timing of the mouth opening. In addition, the community is also influenced by the degree of flow and the ease of movement between lakes. The directional change in water chemistry from an estuarine to a more lacustrine system noted by Russell (2013) needs to be halted. Recognition of the national and international importance of the system dictates that the artificial mouth opening needs to take into consideration biodiversity and ecosystem processes and should only occur at the required height of $2.1 \mathrm{~m}$ above mean sea level. Premature breaching due to human pressure (flooding risk) will only continue to exacerbate the trends in water quality and overall ecosystem functioning. To ensure adequate water flow and fish recruitment throughout the system, restrictions (sediment deposition) within the connecting channels need to be assessed and, where possible, removed. In addition, the dense macrophyte stands occurring within these channels not only restrict water movement but also could limit fish movement. Both submerged and emergent aquatic plants within the channels should be regularly cut. Importantly, the cut plants should be removed from the channel to prevent possible anoxic conditions during decomposition. Monitoring of fish recruitment within and throughout the system should continue to assess efficacy of management actions, whilst research should focus on the impacts of the invasive fish species on endemic species and broader ecosystem functioning.

\section{Acknowledgements}

The National Research Foundation of South Africa and the DST-NRF Centre of Excellence in Invasion Biology are thanked for financial support. This research was conducted under DAFF/DEA permit RES2010/61 and was a SANParks registered research project.

\section{Competing interests}

The authors declare that they have no financial or personal relationships which may have inappropriately influenced them in writing this article.

\section{Authors' contributions}

A.A.O. was responsible for data collection as part of her MSc project, writing the research methods and design section and editing the manuscript. N.C.J. was responsible for data analysis and calculations, writing and editing the manuscript. M.K.S.S. contributed to study conceptualisation, study design, data capture and manuscript editing. O.L.F.W. was the project leader and contributed to study conceptualisation, funding, study design, data collection and editing the manuscript.

\section{References}

Allanson, B.R. \& Whitfield, A.K., 1983, The Limnology of the Touw River floodplain South African National Scientific Programmes Report No. 79, Council for Scientific and Industrial Research, Pretoria.

Beckley, L.E., 1984, 'The ichthyofauna of the Sundays estuary, South Africa, with particular reference to the juvenile marine component', Estuaries 7, 248-258. http://dx.doi.org/10.2307/1352145

Bennett, B.A., 1989, 'A comparison of the fish communities in nearby permanently open, seasonally open and normally closed estuaries in the South-Western Cape, South Africa', South African Journal of Marine Science 8, 43-55.

Bennett, B.A., Hamman, K.C.D., Branch, G.M. \& Thorne, S., 1985, 'Changes in the fish fauna of the Bot River estuary in relation to opening and closure of the estuary mouth', Transactions of the Royal Society of South Africa 45, 449-464. http:// dx.doi.org/10.1080/00359198509519503

Blaber, S.J.M., 1974, 'The population structure and growth of juvenile Rhabdosargus holubi (Steindachner) (Teleostei: Sparidae) in a closed estuary', Journal of Fish Biology 6, 455-460. http://dx.doi.org/10.1111/j.1095-8649.1974.tb04561.x

Blaber, S.J.M., 1978, 'Fishes of the Kosi system', Lammergeyer 24, 28-41.

Bok, A.H., 1979, 'The distribution and ecology of two mullet species in some fresh water rivers in the Eastern Cape, South Africa', Journal of the Limnological Society of South Africa 5, 97-102. http://dx.doi.org/10.1080/03779688.1979.9633193 
Bok, A.H., 1984, 'Freshwater mullet in the Eastern Cape - A strong case for fish ladders', The Naturalist 28, 31-35.

Chumchal, M.M., Nowlin, W.H. \& Drenner, R.W., 2005, 'Biomass-dependent effects of common carp on water quality in shallow ponds', Hydrobiologia 545, 271-277. http://dx.doi.org/10.1007/s10750-005-3319-y

Day, J.H., Blaber, S.J.M. \& Wallace, J.H., 1981, 'Estuarine fishes', in J.H. Day (ed.), Estuarine ecology with particular reference to southern Africa, pp. 197-221, A.A. Balkema, Cape Town.

De Villiers, G., 1987, 'Harvesting harders Liza richardsoni in the Benguela upwelling region', South African Journal of Marine Science 5, 851-862. http://dx.doi. org/10.2989/025776187784522540

Ellender, B.R., Weyl, O.L.F., Shanyengange, M.K. \& Cowley, P.D., 2008, Juvenile population dynamics of Oreochromis mossambicus in an intermittently open estuary at the limit of its natural distribution', African Zoology 43(2), 277-282. http://dx.doi.org/10.3377/1562-7020-43.2.277

Griffiths, S.P., 1998, 'Diversity and distribution of fishes in an intermittently open coastal lagoon at Shellharbour, New South Wales', Wetlands (Australia) 18 $13-24$.

Hall, C.M., 1985, 'Some aspects of the ecological structure of a segmented barrier lagoon system with particular reference to the distribution of fishes', MSc thesis, Department of Ichthyology \& Fisheries Science, Rhodes University.

Hall, C.M., Whitfield, A.K. \& Allanson, B.R., 1987, 'Recruitment, diversity and the influences of constrictions on the distribution of fishes in the Wilderness lakes system, South Africa', South African Journal of Zoology 22, 163-168.

Harrison, T.D., 2005, 'Ichthyofauna of South African estuaries in relation to the zoogeography of the region', Smithiana Bulletin 6, 1-27.

Harrison, T.D. \& Whitfield, A.K., 2004, 'A multi-metric fish index to assess the environmental condition of estuaries', Journal of Fish Biology 65, 683-710. http:// dx.doi.org/10.1111/j.0022-1112.2004.00477.x

Howard-Williams, C. \& Liptrot, M.R.M., 1980, 'Submerged macrophyte communities in a brackish South African estuarine-lake system', Aquatic biology 9, 101-116.

James, N.C., Cowley, P.D. \& Whitfield, A.K., 2007a, 'Abundance, recruitment and residency of two sparids in an intermittently open estuary in South Africa' African Journal of Marine Science 29, 527-538. http://dx.doi.org/10.2989/ AJMS.2007.29.3.18.348

James, N.C., Cowley, P.D., Whitfield, A.K. \& Lamberth, S.J., 2007b, 'Fish communities in temporarily open/closed estuaries from the warm- and cool-temperate regions of South Africa: A review', Reviews in Fish Biology and Fisheries 17, 565-580.

James, N.C. \& Harrison, T.D., 2008, 'A preliminary survey of the estuaries on the south coast of South Africa, Cape St Blaize, Mossel Bay Robberg Peninsula, Plettenberg Bay, with particular reference to the fish fauna', Transactions of the Royal Societ of South Africa 63, 111-127. http://dx.doi.org/10.1080/00359190809519216

James, N.C., Whitfield, A.K. \& Cowley, P.D., 2008, 'Long-term stability of the fish assemblages in a warm-temperate South African estuary', Estuarine, Coastal and Shelf Science 76, 723-738. http://dx.doi.org/10.1016/j.ecss.2007.07.036

Khan, T.A., Wilson, M.E. \& Khan, M.T., 2003, 'Evidence for invasive carp mediated trophic cascade in shallow lakes of western Victoria, Australia', Hydrobiologia 506 465-472.

Kok, H.M. \& Whitfield, A.K., 1986, 'The influence of open and closed mouth phases on the marine fish fauna of the Swartvlei estuary', South African Journal of Zoology 21, 309-315. http://dx.doi.org/10.1080/02541858.1986.11448004

Maree, R.C., Whitfield, A.K. \& Quinn, N.W., 2003, Prioritisation of South African estuaries based on their potential importance to estuarine-associated fish species, WRC Report No. TT 2003/03, Water Research Commission, Pretoria.

Olds, A.A., Smith, M.K.S., Weyl, O.L.F. \& Russell, I.A., 2011, 'Invasive alien freshwater fishes in the Wilderness Lakes System, a wetland of international importance in the Western Cape Province, South Africa', African Zoology 46, 179-184.

Parkos, J., Santucci, V.C. \& Wahl, D., 2003, 'Effects of common carp (Cyprinus carpio) on multiple torphic levels in shallow mewocosms', Canadian Journal of Fisheries and Aquatic Sciences 60, 182-192. http://dx.doi.org/10.1139/f03-011

Potter, I.C., Beckley, L.E., Whitfield, A.K. \& Lenanton, R.C.J., 1990, 'Comparisons between the roles played by estuaries in the life cycles of fishes in temperate Western Australia and Southern Africa', Environmental Biology of Fishes 28, 143-178. http://dx.doi.org/10.1007/BF00751033

Potter, I.C. \& Hyndes, G.A., 1999, 'Characteristics of the ichthyofaunas of the southwestern Australian estuaries, including comparisons with Holarctic estuaries and estuaries elsewhere in temperate Australia: A review', Australian Journal of Ecology 24, 395-421. http://dx.doi.org/10.1046/j.1442-9993.1999.00980.x

Prchalová, M., Kubečka, J., Říha, M., Mrkvička, T., Vašek, M., Jůza, T., et al., 2009, 'Size selectivity of standardized multimesh gillnets in sampling coarse European species', Fisheries Research 96, 51-57. http://dx.doi.org/10.1016/j.fishres.2008. 09.017
Ratte, T.W., 1989, 'Population structure, production, growth, reproduction and the ecology of Atherina breviceps Valenciennes, 1935 (Pisces: Atherinidae) and Gilchristella aestuaria (Gilchrist, 1914) (Pisces Clupeidae), from two southern Cape coastal lakes', PhD thesis, Zoology Department, University of Port Elizabeth.

Russell, I.A., 1996, 'Fish abundance in the Wilderness and Swartvlei lake systems: Changes relative to environmental factors', South African Journal of Zoology 31, 1-9. http://dx.doi.org/10.1080/02541858.1996.11448389

Russell, I.A., 1999, 'Freshwater fish of the Wilderness National Park', Koedoe 42, 73-78. http://dx.doi.org/10.4102/koedoe.v42i1.223

Russell, I.A., 2003, 'Changes in the distribution of emergent aquatic plants in a brackish South African estuarine-lake system', African Journal of Aquatic Science 28, 103-122. http://dx.doi.org/10.2989/16085910309503776

Russell, I.A., 2013, 'Spatio-temporal variability of surface water quality parameters in a South African estuarine lake system', African Journal of Aquatic Science 38 53-56. http://dx.doi.org/10.2989/16085914.2012.742006

SANParks, 2012, Garden Route National Park - Management Plan, viewed 07 Octobe 2015, from http://www.sanparks.org/docs/parks grnp/planning products/ management_plan.pdf

Scott, K.M.F., Harrison, A.D. \& Macnae, W., 1952, 'The ecology of South African estuaries. Part 2: The Klein River estuary, Hermanus, Cape', Transactions of the Royal Society of South Africa 33, 282-331.

Sloterdijk, H., James, N.C., Smith, M.K.S., Ekau, W. \& Weyl, O.L.F., 2015, 'Population dynamics and biology of an invasive population of mosquitofish Gambusia affinis in a temperate estuarine lake system', African Zoology 50(1), 31-40.

Talbot, M.M.J.F., 1982, 'Aspects of the ecology and biology of Gilchristella aestuarius (G \& T) (Pisces: Clupeidae) in the Swartkops estuary', MSc thesis, Zoology Department, University of Port Elizabeth.

Turpie, J.K., Adams, J.B., Joubert, A., Harrison, T.D., Colloty, B.M., Maree, R.C., et al., 2002, 'Assessment of the conservation priority status of South African estuaries for use in management and water allocation', Water SA 28, 191-206. http://dx. doi.org/10.4314/wsa.v28i2.4885

van der Horst, G. \& Erasmus, T., 1981, 'Spawning time and spawning grounds of mulle with special reference to Liza dumerili (Steindachner, 1869)', South African Journal of Science 77, 73-78.

Vorwerk, P.D., Whitfield, A.K., Cowley, P.D. \& Paterson, A.W., 2001, 'A survey of selected Eastern Cape estuaries with particular reference to the ichthyofauna', Ichthyological Bulletin of the J.L.B. Smith Institute of Ichthyology 72, 1-52.

Vorwerk, P.D., Whitfield, A.K., Cowley, P.D. \& Paterson, A.W., 2003, 'The influence of selected environmental variables on fish assemblage structure in a range of selected environmental variables on tish assemblage structure in a range of
southeast African estuaries', Environmental Biology of Fishes 66, 237-247. http:// southeast African estuaries', Environment

Wallace, J.H., 1975, 'The estuarine fishes of the east coast of South Africa. Part 1. Species composition and length distribution in the estuarine and marine Species composition and length distribution in the estuarine and marine of the Oceanographic Research Institute 40, 1-72.

Wallace, J.H. \& van der Elst, R.P., 1975, 'The estuarine fishes of the east coast of South Africa. Part 4. Occurrence of juveniles in estuaries. Part 5. Ecology, estuarine dependence and status', Investigational Report of the Oceanographic Research Institute 42, 1-63.

Weber, M.J. \& Brown, M.L., 2009, 'Effects of common carp on aquatic ecosystems 80 years after "carp as a dominant": Ecological insights for fisheries management', Reviews in Fisheries Science 17, 524-537. http://dx.doi.org/10.1080/10641260903189243

Weisser, P.J. \& Howard-Williams, C., 1982, 'The vegetation of the Wilderness Lakes system and the macrophyte encroachment problem', Bontebok 2, 19-40.

Whitfield, A.K., 1994, 'An estuary-association classification for the fishes of southern Africa', South African Journal of Science 90, 411-417.

Whitfield, A.K., 1998, Biology and ecology of fishes in Southern African Estuaries, Ichthyological Monographs of the J.L.B. Smith Institute of Ichthyology, No 2 Grahamstown.

Whitfield, A.K. \& Blaber, S.J.M., 1979, 'The distribution of the freshwater cichlid Sarotherodon mossambicus in estuarine systems', Environmental Biology of Fishes 4arotherodon mossambicus in estuarine systems',

Whitfield, A.K. \& Elliott, M., 2002, 'Fishes as indicators of environmental and ecological changes within estuaries: A review of progress and some suggestions for the future', Journal of Fish Biology 61(Suppl A), 229-250. http://dx.doi. org/10.1111/j.1095-8649.2002.tb01773.x

Whitfield, A.K. \& Kok, H.M. 1992. 'Recruitment of juvenile marine fishes into permanently open and seasonally open estuarine systems on the southern coast of South Africa', Ichthyological Bulletin, 57, 1-15.

Young, G.C., Potter, I.C., Hyndes, G.A. \& de Lestang, S., 1997, 'The ichthyofauna of an intermittently open estuary: Implications of bar breaching and low salinities on faunal composition', Estuarine, Coastal and Shelf Science 45, 53-68. http://dx.doi. org/10.1006/ecss.1996.0165 